\title{
Pedagogia do Oprimido - um grito manso e de esperança
}

\author{
Pedagogy of the Oppressed - a soft and hopeful scream \\ Pedagogía del Oprimido - un grito manso y de esperanza \\ VALDO HERMES DE LIMA BARCELOS $\odot$ \\ Universidade Federal de Santa Maria (UFSM). Santa Maria, RS, Brasil.
}

\begin{abstract}
RESUMO
Este artigo tem como objetivo fazer uma reflexão sobre a atualidade e a pertinência da obra Pedagogia do Oprimido, de Paulo Freire. Frente ao imenso legado freireano algo se pode considerar um consenso: uma grande dose de esperança em um mundo melhor. Esperança para Freire tinha que ver com o verbo esperançar. Nos tempos difíceis atuais da vida política brasileira, de surgimento de uma onda neoconservadora em todas as dimensões da sociedade, onde uns tantos propõem a expulsão de Freire e de seu legado das escolas e das universidades, há que aprofundarmos e atualizarmos a compreensão do legado freireano. Ou seja: aos que propõem "escolas sem partido" e expulsão de Freire, devemos responder com mais Freire e com mais democracia. Se tivéssemos conseguido fazer as proposições freireanas mais presentes em nossa educação, certamente que alguns ressurgimentos obscurantistas teriam mais dificuldades para se instalar em nossa sociedade.
\end{abstract}

Palavras-chave: Pedagogia do Oprimido. Grito manso. Legado de esperança. Onda neoconservadora.

\begin{abstract}
This article has as its goal to reflect on the relevance and topicality of Pedagogy of the Oppressed by Paulo Freire. Facing the immense legacy by Freire, something may be considered as a consensus: a big dose of hope of a better world. Hope to Freire meant to hope, as a verb. In the difficult present times of Brazilian politics, of emergence of a neoconservative wave in all of society's dimensions, where many may propose the expulsion of Freire and his legacy from schools and universities, the understanding of Freire's legacy has to be deepened and updated. That means: to those who propose the "non-party schools" and Freire's expulsion, we should answer with more Freire and more democracy. If we had managed to make Freire's propositions more present in our education, surely certain obscure resurrections would have had more difficulties to install themselves into our society.
\end{abstract}

Keywords: Pedagogy of the Oppressed. Soft scream. Llegacy of hope. Neoconservative wave.

\section{RESUMEN}

Este artículo tiene como objetivo hacer una reflexión sobre la actualidad y la pertinencia de la obra Pedagogía del Oprimido de Paulo Freire. Frente al inmenso legado freireano algo se puede considerar un consenso: una gran dosis de esperanza en un mundo mejor. Esperanza para Freire tenía que ver con el verbo esperanzar. En los tiempos difíciles actuales de la vida política brasileña, de surgimiento de una ola neoconservadora en todas las dimensiones de la sociedad, donde unos tantos proponen la expulsión de Freire y de su legado de las escuelas y de las universidades, hay que profundizar y actualizar la comprensión del legado freireano. Es decir: a los que propone "escuelas sin partido" y expulsión de Freire, debemos responder con más Freire y con más democracia. Si hubiéramos logrado hacer las proposiciones freireanas más presentes en nuestra educación, seguramente ciertos resurgimientos oscurizantes tendrían más dificultades para instalarse en nuestra sociedad.

Palabras clave: Pedagogía del Oprimido. Grito manso. Legado de esperanza. Onda neoconservadora. 


\section{INTRODUÇÃo}

"No es posible vivir plenamente
como ser humano sin esperanza.
Conserven la esperanza."
(Paulo Freire, 2003, p. 25)

Muitas e importantes foram as mensagens deixadas pelo educador brasileiro e cidadão do mundo, Paulo Reglus Neves Freire (1921-1997). Contudo, algo sempre caracterizava essas mensagens: uma grande dose de esperança em um mundo melhor. Esperança para Paulo Freire tinha que ver com o verbo esperançar.

Para Freire todo(a) educador(a) que mereça essa denominação, não pode abrir mão da busca permanente, e, essa busca tem a ver com a capacidade de ter esperança. Esperança não como uma espera passiva, como uma espera vã. Esperança do verbo esperançar que tem a ver com ir atrás daquilo que se quer, daquilo que se acredita. Assim vista, esperançar é uma ação. Diferente de espera, que tem que ver com passividade, com ficar esperando que as coisas aconteçam. Nesse sentido, a esperança é vista como a possibilidade humana radical de educarse pelo inacabamento. Esse inacabamento do humano é um inacabamento muito especial. Freire não se cansava de frisar que todo ser vivo é inacabado. Contudo, para ele, a diferença reside no fato de que homens e mulheres sabem que são inacabados, enquanto um beija-flor ou um leão não têm essa compreensão - talvez porque dela não precise. Como ensinava (FREIRE, 2003b, p. 30) "Yo soy inacabado, el árbol también ló és, pero yo soy mas incabado por que lo se". Freire vê o educador como um eterno buscador. Nesse sentido, a esperança ${ }^{1}$ e a busca caminham juntas no ato de educar para a liberdade, para a democracia, para a solidariedade e para a cooperação. Enfim, educar para a construção de um mundo melhor. Melhor na perspectiva de mais justo e ecologicamente viável.

Uma das formas com que Freire materializava a esperança era acreditando, era apostando, na capacidade das gentes de sua terra. Das gentes do Brasil. Esperança para Freire era um grito. Porém, não era um grito de raiva. Era um grito generoso, era um grito manso ${ }^{2}$. O próprio Freire gostava de se intitular um "sujeito manso".

Paulo Freire nasceu na cidade do Recife no dia 19 de setembro do ano de 1921. Filho de Joaquim Temístocles

\footnotetext{
1 Esperança aqui tomada no sentido freireano do verbo esperançar, notadamente explicitada no livro Pedagogia da Esperança - um reencontro com a pedagogia do oprimido (Paz e Terra, 1992).

2 Paulo Freire - El grito manso é o título de uma obra publicada pela editora siglo veinteuno, Buenos Aires, 2003. A obra resulta de aulas ministradas por Paulo Freire por ocasião do recebimento do título de Doutor Honoris Causa pela Universidad de San Luis-Argentina no ano de 1996.
}

Freire, que era capitão da Polícia Militar do Estado de Pernambuco, e de Edeltrudes Neves Freire, que para os familiares era chamada de Tudinha. Freire teve uma irmã, Stela, professora primária, e dois irmãos: Temístocles e Armando, aos quais Freire sempre foi muito grato. Os irmãos, em função das condições econômicas precárias da família, não concluíram seus estudos básicos para começar muito cedo a trabalhar. Contudo, não mediram esforços no sentido de proporcionarem a Freire a possibilidade de estudar e formar-se na Universidade. Freire foi casado duas vezes. Primeiro com Elza Freire (1944-1986) com quem teve cinco filhos. A segunda esposa foi Ana Maria Araújo Freire (Nita). Freire formou-se em Direito pela Universidade do Recife no ano de 1943. Contudo, abandonou a carreira logo após a primeira causa que defendeu. Percebeu, muito cedo, que a profissão de advogado não lhe traria felicidade em função da distância entre a Justiça e o Direito. Começou a carreira de professor ensinando Língua Portuguesa no ensino médio. Paulo Freire foi convidado no ano de 1946 para ocupar o cargo de diretor do Departamento de Educação e Cultura do Serviço Social no estado de Pernambuco. Foi a partir de então que Paulo Freire dedicou-se, com grande afinco, ao trabalho com a alfabetização de jovens e adultos. Voltou sua atenção, particularmente, ao trabalho com os mais pobres. Costumava dizer que, à época, jamais poderia imaginar a repercussão dessa decisão em sua vida.

Essa atitude tomada o levou à construção de uma proposta revolucionária de alfabetização de adultos pobres, em grande parte, camponeses do interior do Nordeste brasileiro. Com sua proposta ou "método" de alfabetização foi capaz de alfabetizar 300 adultos cortadores(as) de cana-de-açúcar em um curto período de 45 dias. O educador Paulo Freire acabou tornando-se uma referência e uma inspiração para muitas gerações de professores(as), no Brasil, na América Latina e no continente africano. Seu trabalho foi reconhecido nos cinco continentes. Recebeu o título de Doutor Honoris Causa nas maiores e mais prestigiadas universidades do mundo. Foram nada mais nada menos que 27 Títulos de Doutor Honoris Causa. Paulo Freire ganhou ainda prêmios como: Educação para a Paz (das Nações Unidas, 1986) e Educador dos Continentes (da Organização dos Estados Americanos, 1992).

Foi esse envolvimento com a alfabetização de jovens e adultos pobres, inevitavelmente, o levou a despertar desconfiança em um primeiro momento e muito ódio em seguida. Sua proposta política de educação ia totalmente contra o que queriam e defendiam às propostas das elites e dos governos da época. Tal contexto o levou a todo tipo de tentativa de difamação. Até de "traidor da pátria" foi chamado por muitos integrantes da elite rica do País. Teve importante militância política, fazendo parte da primeira 
diretoria executiva da Fundação Wilson Pinheiro. Foi Secretário de Educação (1989-1991) da Prefeitura de São Paulo na Gestão da prefeita Luiza Erundina. Com o golpe militar de 1964, Paulo Freire foi preso por 70 dias em um quartel do Exército em Recife. Durante a prisão aconteceram fatos pitorescos e que Freire gostava de narrar em suas conferências como forma de não ficar amargurado em excesso com as adversidades pelas quais passou. Freire era um sujeito bem-humorado e que gostava de uma longa e calma conversa.

Paulo Freire morreu como viveu. Cheio de amorosidade, com sua gente e de indignação com as injustiças e "malvadezas" dos poderosos e dos tiranos. Semeou bonitezas por onde passou. Freire fez legítima a máxima do poeta mexicano Octávio Paz (1914-1998) quando esse afirmava que se "Morrestes de forma diferente daquela que viveu, é sinal de que não foi tua a vida que vivestes" (PAZ, 1994, p. 356). Era a madrugada do dia 2 de maio de 1997, às cinco e meia da manhã, quando sua passagem foi registrada no leito hospitalar onde estava internado.

\section{SONHO E REALIDADE: DOIS CAMINHOS A REALIZAR}

\author{
"É possivel a vida sem sonho, mas não \\ existência humana e história sem sonho."
}

(Paulo Freire, 1992)

Paulo Freire, mesmo sendo um sonhador inveterado, nunca se descolou da realidade em que vivia. Ao contrário, era dela que partia para pensar suas proposições e suas ações na direção da construção de uma educação para a autonomia, para uma educação como prática de liberdade, enfim para a construção de uma sociedade mais justa e generosa. Costumava dizer que "A realidade não é assim, está assim” (FREIRE, 2003b, p. 71).

No encerramento do prefácio para a $60^{\mathrm{a}}$ edição comemorativa do livro Pedagogia do Oprimido, publicada pela editora Paz e Terra (2016), o professor e pesquisador da obra freireana Celso de Rui Beisiegel, assim encerra seu texto: "A qualidade, a riqueza e a generosidade das propostas e ideais que permeiam toda a sua obra encontram-se forte e claramente marcadas em Pedagogia do Oprimido" (BEISIEGEL, 2016, p. 31). Freire chegou ao livro Pedagogia do Oprimido fazendo um caminho de reflexões que ficaram registradas em importantes textos, palestras proferidas em vários países, bem como em livros. Se os escritos de Freire, que antecederam a publicação do livro Pedagogia do Oprimido, foram fundamentais para a concretização dessa obra, pode-se dizer, também, que esse livro se esparramou, encharcou toda a produção freireana posterior a ela. Pedagogia do Oprimido foi como que um aprofundamento e um adensamento dos escritos de Freire até então. Com Pedagogia do Oprimido Paulo Freire apresenta de forma incisiva, e mesmo radical, suas análises sobre as injustiças sociais em uma sociedade organizada na perspectiva de opressores(as) e de oprimidos(as). O caráter fortemente político da obra freireana ganha, com Pedagogia do Oprimido, um impulso que não mais pode ser freado. Talvez essa tenha sido uma das motivações para os tantos ataques que Freire e sua obra receberam ao longo do tempo de parte das elites reacionárias e dos defensores de uma educação elitista, de orientação bancária e discriminatória. Ressalte-se que esses ataques têm recrudescido nos últimos tempos.

Se existe algo que pode ser considerado um consenso sobre a obra de Paulo Freire, tanto antes como após a publicação de Pedagogia do Oprimido, é a presença da sua preocupação com a realidade vivida dos homens e das mulheres na sociedade brasileira. Particularmente com os grandes contingentes de abandonados a própria sorte pelas elites intelectuais e políticas do Brasil. Pensar a obra de Freire sem os brasileiros e brasileiras reais é algo definitivamente impossível. Não por acaso no livro Educação como Prática da Liberdade (FREIRE, 1965), livro que antecedeu o Pedagogia do Oprimido, Paulo Freire faz um Esclarecimento introdutório em que escreve: "Não há educação fora das sociedades humanas e não há homem no vazio" $(1965$, p. 35). Freire oferece esse livro - Educação como Prática da Liberdade - a todas as pessoas que no Brasil continuavam resistindo ao autoritarismo da época, bem como àqueles e àquelas que, como ele, tiveram que se exilar em outros países. Sem esquecer-se de mencionar os que estavam sendo presos e torturados nos porões da ditadura militar que se instalou no Brasil pós-1964.

Essa permanente preocupação de Paulo Freire com a realidade vivida pela sociedade brasileira ele fazia questão de ressaltar quando se referia aos seus conterrâneos os chamando de "minha gente". A expressão "gente", frequentemente utilizada por Freire, tinha uma conotação muito particular, tanto do ponto de vista sociológico, antropológico quanto pedagógico. Uma demonstração dessa importância, temos registrada quando Freire afirma, textualmente, que como educadores(as), não podemos nunca nos esquecer de que, em educação, lidamos com gente e não com coisas. Nas suas palavras,

Lido com gente e não com coisas. E porque lido com gente, não posso, por mais que, inclusive, me de prazer entregar-me à reflexão teórica e crítica em torno da própria prática docente e discente, recusar minha atenção dedicada e amorosa à problemática mais pessoal deste ou daquele aluno ou aluna (FREIRE, 1997, p. 32). 
Essa admiração pelas gentes do Brasil foi sempre levada e demonstrada por Freire nos diferentes lugares onde trabalhou e viveu. Não escondia a sua imensa paixão pelas gentes do Brasil, em especial, pelos marginalizados, pelos pertencentes às periferias excluídas pelas elites econômicas, intelectuais e acadêmicas. Não podemos esquecer que as elites brasileiras se mostraram - e ainda se mostram - uma das mais arrogantes e perversas do planeta. Para Freire, uma das formas de evitar cair nas armadilhas da arrogância e da prepotência, tão ao gosto de uma elite que vivia de costas para o Brasil real, era não esquecer, nunca, que o trabalho do educador em uma sociedade tão injusta como a nossa, é um trabalho com gente. Nas suas palavras,

Gente em permanente processo de busca. Gente formando-se, mudando, crescendo, reorientando-se, melhorando, mas, porque gente, capaz de negar os valores, de distorcer-se, de recusar, de transgredir... Lido, por isso mesmo, independentemente do discurso ideológico negador dos sonhos e das utopias, com os sonhos, as esperanças tímidas, às vezes, mas às vezes, fortes dos educandos. Se não posso, de um lado, estimular os sonhos impossíveis, não devo, de outro, negar a quem sonha o direito de sonhar. Lido com gente e não com coisas (FREIRE, 1997, p. 144).

Essa vinculação tão estreita, tão encarnada nas pessoas reais e em suas vicissitudes cotidianas certamente teve importante papel no fato de seu livro Pedagogia do Oprimido - como de resto sua obra - tenham sido tão debatidos em vários continentes. Um clássico, na melhor acepção que se possa dar a essa palavra. Freire e sua obra continuam atuais. No livro La voz del Maestro, acerca de vivir, enseñar y transformar el mundo ${ }^{3}$, publicado na Argentina pela editora Siglo Veintiuno (2018), reafirma a necessidade de buscarmos compreender o mundo que se vive, o tempo que se vive para, assim, nos mantermos nele inseridos e não alienados. Freire se autodefinia como uma pessoa que nunca desistia de refletir sobre as condições reais da vida real de sua gente. Nas suas palavras: "Soy um hombre de hoy" (FREIRE, 2018, p. 17).

Pedagogia do Oprimido teve a influência das publicações anteriores de Freire, mas, também, de sua passagem pelo Serviço Social da Indústria (SESI), do Estado de Pernambuco. Freire assumiu a recémcriada Divisão de Educação e Cultura. Nas palavras do próprio Freire: "Campo de experiência, de estudo, de reflexão, de prática, se constituiu como um momento indispensável à gestação da Pedagogia do Oprimido" (FREIRE, 1992a, p. 19). Freire resume a construção da

\footnotetext{
3 Originalmente publicado com o título de Conversação Libertária com Edson Passetti. São Paulo, 1998. Imaginário.
}

Pedagogia do Oprimido ao escrever que "A Pedagogia do Oprimido não poderia ter sido gestada em mim só por causa de minha passagem pelo SESI, mas a minha passagem pelo SESI foi fundamental" (1992a, p. 18). De outra forma, Freire também coloca como de grande influência na construção de Pedagogia do Oprimido a sua Tese intitulada Educação e Atualidade brasileira (1959) apresentada na Universidade Federal do Recife. Essa tese, por seu turno, deu origem ao decisivo Educação como Prática da liberdade e esse, se desdobra, em muito, em anunciar o que viria a ser a Pedagogia do Oprimido.

Vale lembrar que a primeira publicação de Pedagogia do Oprimido não foi na língua portuguesa e sim em inglês, no ano de 1970. Talvez esse fato tenha tido, também, grande importância para a ampla aceitação que o livro teve já à época. Publicado inicialmente em língua inglesa, em Nova York, logo foi traduzido para o espanhol, italiano, o alemão, o sueco e o holandês. (BEISIEGEL, 2016). Só em 1974 saiu à primeira edição brasileira pela editora Paz e Terra.

Com Pedagogia do Oprimido Freire fez o exercício fundamental para qualquer intelectual que mereça realmente essa denominação: partiu da busca do entendimento profundo da realidade vivida para construir a realidade sonhada. Esse exercício, pensamos que ele sintetizou, magistralmente, na expressão: "La realidad no es a si, está a si... A realidade não é assim, está assim".

No segundo capítulo do livro Pedagogia do Oprimido Freire dedica uma densa reflexão sobre o que ele denomina de uma concepção "Bancária" da educação. Essa concepção de educação, segundo Freire, está marcada por relações que ele denomina de relações narradoras e dissertadoras (FREIRE, 2016, p. 103). Esse tipo de relação se dá entre dois personagens, a saber: o sujeito, que corresponde ao narrador e os objetos que correspondem aos educandos(as) que, como objetos, sua condição é de meros ouvintes ou coadjuvantes. É evidente nesse tipo de relação o interesse de manter o educando(a) na passividade. Seu papel é de mero expectador e sua participação se resume a aceitação, assimilação e reprodução dos conteúdos "depositados" pelo narrador/ dissertador, no caso em questão o educador. O processo educativo como que se resume a um ato mecânico de narrar e narrar sobre uma dada realidade apresentada pelo educador ao educando. Realidade, essa, que não the pertence ou que da mesma o educando nada, ou muito pouco, teria a dizer. Vamos ao que sobre essa relação escreve Freire para quem nessa perspectiva educacional o que acontece é,

Falar da realidade como algo parado, estático, compartimentado e bem-comportado, quando não falar ou dissertar sobre algo completamente alheio à 
experiência existencial dos educandos, vem sendo, realmente, a suprema inquietação desta educação. A sua irrefreada ânsia. Nela, o educador aparece como seu indiscutível agente, como seu real sujeito, cuja tarefa indeclinável é "encher" os educandos dos conteúdos de sua narração (FREIRE, 2016, p. 104).

Com tal método o que se tem é um completo desprezo pelo educando(a) e sua experiência vivida. Nega-se a esse(a) educando(a) sua própria condição de sujeito. A aprendizagem se resume a receber e assimilar, como seus, desde os conhecimentos via os conteúdos apresentados, quanto os valores culturais do narrador/dissertador. Assim que, os conteúdos que os educandos devem assimilar podem ser totalmente estranhos ao mundo vivido, ou seja, desconectados, estranhos a sua realidade. Com isso a palavra veiculada nessa dissertação é uma palavra vazia, oca. Para Freire o desfecho dessa prática é que a palavra, que deveria ser transformadora da realidade, se resume a mera sonoridade a ser assimilada pelo(a) educando(a). Fecha-se, assim, um círculo quase perfeito para uma relação de objetificação entre educador(a) e educando(a), pois, "Na visão bancária da educação, o "saber" é uma doação dos que se julgam sábios aos que julgam nada saber" (FREIRE, 2016, p. 105).

Ao negar ao educando(a) o direito de ter reconhecida sua capacidade, como sujeito humano, de entendimento do mundo em que vive comete-se um verdadeiro crime contra sua humanidade. $\mathrm{O}$ crime de desejar mantê-lo no mundo da alienação. Nessa prática educativa o educador que consegue realizar seu objetivo será reconhecido como educador eficiente e sua prática educativa tida como eficaz. Já aos educando(as) cabe o papel de aceitar docilmente seu lugar de mero objeto de uma educação "bancária". Com isso realiza-se o objetivo da educação "Bancária": "Como um ato de depositar, em que os(as) educandos(as) são os depositários e o educador, o depositador" (FREIRE, 2016, p. 105). O saber que daí decorre deixa de ser o que Freire denomina de "saber da experiência feito", para se tornar em um saber de experiência narrada ou transmitida. A consciência crítica, tão importante em um processo de educação libertadora, defendido por Freire no Pedagogia do Oprimido fica relegado ao total desprezo.

A educação como uma janela para a inserção dos sujeitos no mundo, a partir do entendimento da realidade vivida, se transforma, simplesmente, em mais um mecanismo de dominação e de alienação. A condição de sujeitos de suas vidas lhes é tomada. O papel de transformação pela educação fica completamente anulado nessa perspectiva de educação "Bancária". Essa preocupação freireana, e essa compreensão política da necessidade de romper com o modelo de educação, onde educados(as) são meros objetos da educação alienante, já se faz presente no livro Educação como Prática da Liberdade (1965) quando o autor alerta para a necessidade de uma educação para as amplas camadas da população brasileira excluídas do processo de participação na vida política e das riquezas produzidas no país. Riquezas, essas, decorrentes da exploração da força de trabalho em condições as mais precárias. $\mathrm{Na}$ primeira parte de Educação como Prática da Liberdade - intitulada Esclarecimentos -, escrita em Santiago do Chile (1965), Freire chama a atenção para a necessidade de uma educação que rompa com a perspectiva de educação "Para o homem-objeto" e se encaminhe para uma educação para o "homem-sujeito" (FREIRE, 1965, p. 37).

É esse homem e essa mulher, sujeitos de sua história, que são o sentido e objetivo de uma educação como prática da liberdade e da autonomia propostas por Freire. Paulo Freire não se cansava de alertar para o fato de que uma educação que mereça realmente essa denominação, não pode esquecer-se que a realidade dos educandos e educandas não pode ser pensada sem sonhos, pois, até se pode pensar vida humana sem sonhos, jamais existência humana e histórica sem a boniteza de sonhar um mundo mais justo e fraterno. De outra forma, o papel do educador(a) não é nunca, "Falar ao povo sobre nossa visão do mundo, ou tentar impô-la a ele, mas dialogar com ele sobre a sua e a nossa" (FREIRE, 2016, p. 146). Como educadores(as) há que estarmos cientes de que a visão de mundo, o entendimento da realidade dos educandos e educandas, nada mais é que as suas visões de mundo e que refletem, assim, "Sua situação no mundo, em que se constitui. A ação educativa e política não pode prescindir do conhecimento crítico dessa situação, sob pena de se fazer "bancária" ou de pregar no deserto" (FREIRE, 2016, p. 147). Como se pode perceber, é marcante na obra de Freire em geral, e na Pedagogia do Oprimido em particular, essa permanente preocupação com o diálogo entre educadores(as) e educandos(as). Diálogo esse que, só será possível se realizar a partir da busca sincera e generosa de aproximação de educadores(as) e de educandos(as), tendo, como ponto de partida a realidade dos segmentos populares. Para Freire, ou reconhecemos a necessidade de mergulhar junto com educandos(as) em sua realidade ou estaremos nos restringindo a simples portadores(as) de boas vontades e de discursos ocos.

Não por acaso o educador Ernani Maria Fiori (19141985) inicia o Prefácio de Pedagogia do Oprimido afirmando: "PAULO FREIRE É UM PENSADOR comprometido com a vida: não pensa ideias, pensa a existência" (FIORI, 2016, p.34, grifo do autor). Um pensador que, ao mesmo tempo em que vive o tempo presente, não descuida de atualizar o que já foi. Em Pedagogia do Oprimido Freire falou a partir de 1968, mas continua contemporâneo naquilo que é sua maior 
substância: a busca de uma educação libertadora de homens e de mulheres no tempo em que vivem suas existências. Assim visto, faz jus ao que escreveu Freire ao se referir ao seu Pedagogia do Oprimido, como um livro que não diz do que foi, mas, sim, um livro que está sendo.

\section{SONHOS E REALIDADE - O INÉDITO VIÁVEL}

Amigo, se você veio aqui pensando que ia ensinar nós a derrubar o pau, nós tem de dizer a você que não tem precisão. Nós já sabe derrubar o pau. O que nós quer saber é se você vai tá com nós na hora do tombo do pau (FREIRE, 2003).

Em Pedagogia da Esperança - um reencontro com a Pedagogia do Oprimido. Freire desabafa ao dizer que é esse, um livro que escreve com amor, mas, também, com raiva. Justifica isso, dizendo que é essa raiva e esse amor que fazem nascer a esperança. Freire deu uma importância muito grande para a proposição do inédito viável $^{4} \mathrm{em}$ sua obra. Não por acaso, retoma essa proposição, cunhada no Pedagogia do Oprimido, em Pedagogia da Esperança - um reencontro com a Pedagogia do Oprimido. Faz essa retomada como forma de demonstrar a atualidade de Pedagogia do Oprimido décadas depois. Atualidade, essa, que entendo ainda muito presente, cinquenta anos depois.

No capítulo 4 do livro Pedagogia do Oprimido, ao tratar da Teoria da Ação Antidialógica, Paulo Freire afirma textualmente que: "Não há realidade histórica mais outra obviedade - que não seja humana" (FREIRE, 2016, p.203). As razões para isso seriam óbvias, pois, "Não há história sem homens, como não há uma história para os homens, mas uma história de homens que feita por eles, também se faz" (FREIRE, 2016, p. 204). Fica explícita, nessa formulação que, para Freire, homens e mulheres não são objetos da história ou objetos a serem pesquisados, estudados pelas elites. Freire é enfático sobre essa condição ao afirmar que: "O mundo não é um laboratório de anatomia nem os homens são cadáveres que devam ser estudados passivamente" (2016, p. 208). Entendo essa formulação freireana como uma forma de colocar homens e mulheres não na periferia, mas, sim, no centro do fazer da história. Assim tomado o papel de homens e mulheres, na realidade em que vivem, podemos

\footnotetext{
${ }^{4}$ Freire ao apresentar essa proposição do "inédito viável" em Pedagogia do Oprimido, coloca que homens e mulheres se defrontam em sua existência com obstáculos e dificuldades. A essas dificuldades Freire denomina de "situações-limites". Segundo o educador, a ação frente a essas situações limites podem ser de aceitação, mas, também, de enfrentamento. As pessoas que optam pela segunda alternativa, são aquelas que vão a busca da realização de seus sonhos, da viabilização de suas utopias. É essa busca que poderá alcançar o que Freire denominou em Pedagogia do Oprimido de "inédito-viável".
}

afirmar que homens e mulheres, além de fazerem parte da história, podem assumir seus destinos e fazerem, assim, a história. Diferentemente dos outros animais, homens e mulheres são, para Freire, seres do quefazer. Em função disso que seu quefazer é ação e reflexão. Nas suas palavras: "É práxis. É transformação do mundo. E, na razão mesma em que o quefazer é práxis, todo fazer do quefazer tem de ter uma teoria que necessariamente o ilumine. O quefazer é teoria e prática. É reflexão e ação" (FREIRE, 2016, p. 196). Com isso, para Freire, o quefazer não se reduz ao mero discurso sobre ou em nome de alguém. Ao contrário, é algo concreto para além do ativismo ou do mero verbalismo.

Ao refletir sobre a relação entre lideranças e oprimidos, Freire não se cansa de chamar a atenção para o perigo da manipulação dos oprimidos pelos líderes. Freire não aceita que a liderança tome os liderados como incapazes de fazerem e/ou executarem sua história. É a partir da assunção de seu papel de "fazedores e fazedoras" da história que homens e mulheres passam da condição de "homem-objeto" para "homem-sujeito" apontados por Freire no Pedagogia do Oprimido. Esse papel de donos de sua história é tão fundamental na obra freireana em geral, e, particularmente, na Pedagogia do Oprimido, que o educador faz questão de alertar, inclusive, para o risco de mesmo defensores de movimentos revolucionários tomarem os setores oprimidos como seus objetos de ação política. Sobre isso, em Pedagogia do Oprimido, Freire é radical e alerta que "O humanista científico revolucionário não pode, em nome da revolução, ter nos oprimidos objetos passivos de sua análise, da qual decorrem prescrições que eles devam seguir" (FREIRE, 2016, p. 208). A maneira de evitar esse equívoco histórico e político é a liderança revolucionária, científico e humanista evitar repetir a prática das elites dominadoras de levar às últimas consequências a ideia de ignorância das massas populares. Setores progressistas não podem, jamais, "Crer nesse mito. Não tem sequer o direito de duvidar, por um momento, de que isto é um mito" (FREIRE, 2016, p. 209).

Freire dedica uma longa reflexão sobre essa possibilidade em Pedagogia do Oprimido, certamente por temer a manipulação de suas "gentes" por parte de oportunistas e manipulares que acreditam que os fins justificam os meios de ação. Vamos a mais uma manifestação de Freire sobre essa questão fundamental. Para ele,

Nenhuma liderança pode admitir que só ela sabe e que só ela pode saber - o que seria descrer das massas populares. Ainda quando seja legítimo reconhecer-se em um nível de saber revolucionário, em função de sua mesma consciência revolucionária, diferente do nível de conhecimento ingênuo das massas, não pode sobrepor-se a este, com o seu saber (FREIRE, 2016, p. 210). 
Essa preocupação de Freire é mais um exemplo de sua lucidez política e de sua capacidade de análise, já à época, dos desfechos de embates no continente latino-americano, e mesmo no mundo, entre setores progressistas e setores reacionários autoritários. Freire traduz essa sua visão sobre o processo de libertação quando afirma textualmente que "Ninguém liberta ninguém, ninguém se liberta sozinho: os homens se libertam em comunhão" (FREIRE, 2016, p.95). A realização da libertação de homens e de mulheres que se encontram em condição de subjugação não pode ser vista como uma libertação que vem de outro, que vem de fora. Para Freire, essa libertação precisa ser entendida como uma libertação de pessoas, pois, não podemos nos esquecer, nunca, que em educação estamos lidando com gente. Nas suas palavras:

Estamos lidando com homens e não com coisas. Por isso, se não é autolibertação - ninguém se liberta sozinho -, também não é libertação de uns feita por outros. Não se pode realizar com os homens pela "metade". E, quando o tentamos, realizamos a sua deformação (FREIRE, 2016, p.97).

A maneira mais direta de evitar-se que essa libertação seja mais um processo de "enganação" e não de verdadeira libertação é, para Freire, o caminho do diálogo. A opção pela busca de sua libertação deve ser uma opção consciente feita pelos oprimidos e não uma dádiva trazida por um "iluminado". Nessa perspectiva epistemológica a libertação proposta por Freire não é uma "Doação que lhes faça a liderança revolucionária, mas resultado de sua conscientização" (2016, p. 99). Essa compreensão até pode ser vista como mais uma obviedade, contudo nem sempre é percebida por algumas lideranças que até se denominam de revolucionárias. As comunidades populares precisam perceber por sua própria reflexão - e aí sim fazer sua opção consciente - a possibilidade de sua inserção na realidade vivida e, a partir dessa constatação perceber que essa realidade pode, sim, ser por elas transformada na direção de uma sociedade mais justa e generosa.

Com isso, seria dado o primeiro passo na direção da passagem da realidade vivida para a realidade sonhada. Como na epígrafe que coloquei no início desse item, mais que a pretensão de "ensinar" ao outro - coisas que às vezes ele já sabe e não sabemos que ele sabe - há que se estar junto a ele nas horas da "precisão". Esse estar junto é a materialização da solidariedade e generosidade com aqueles(as) que, via de regra, são esquecidos(as) pelas elites políticas e econômicas detentoras das estruturas de poder. Como na fala do pequeno agricultor: "Nós já sabe derrubar o pau. O que nós quer saber é se você vai tá com nós na hora do tombo do pau" (FREIRE, 2003b, p. 35). Esse estar junto na realidade vivida leva educando(a) e educador(a) a serem parceiros em uma tarefa cooperativa.
Nesse processo de estar junto, e cooperar, se encontram dois sujeitos e não um sujeito e um objeto. Em tal tipo de processo acontece aquilo que Freire busca demonstrar em toda sua obra, e em especial no Pedagogia do Oprimido: sujeitos "cointencionados à realidade, se encontram numa tarefa em que ambos são sujeitos no ato, não só de desvelá-la e, assim, criticamente conhecê-la, mas, também, no de recriar este conhecimento" (FREIRE, 2016, p.101). Ao comungarem essa ação homens e mulheres "Alcançam, na reflexão e na ação em comum, este saber da realidade, se descobrem como seus refazedores permanentes" (FREIRE, 2016, p.103).

Acrescentaria apenas: Fazedores(as) e refazedores(as) de sonhos e realizadores(as) de utopias. Artífices de seus inéditos viáveis, transformando a realidade que está assim, em uma realidade outra: uma realidade antes ousada ser sonhada.

\section{CONSIDERAÇÕES FINAIS}

"Não há educação fora das sociedades humanas e não há homem no vazio."

(FREIRE, 1981)

No livro intitulado El Grito Manso (2003b) Freire manifesta, mais uma vez, sua esperança nas mudanças que homens e mulheres podem promover na sociedade em que vivem. Para ele, sempre foi incompreensível que tanta gente, inclusive alguns colegas seus de universidade, aceitassem certas injustiças sociais como fatalidades. Nas suas palavras: "No hay nada que este fatalmente determinado en el mundo de la cultura... no hay fatalismo en la conducta humana... Hay que pelear" (FREIRE, 2003a, p. 78).

Pode-se perceber que essa esperança inabalável de Freire na potência das gentes do Brasil, tão presente em Pedagogia do Oprimido, percorreu toda sua obra. Paulo Freire dá início ao seu livro Pedagogia da Esperança um reencontro com a Pedagogia do Oprimido (1992b), descrevendo a forma assombrada com a qual algumas pessoas se manifestavam em relação ao título do referido livro. Eram alguns colegas seus de universidade e até parceiros de engajamento na busca de uma educação libertadora. Conta que um colega seu de universidade assim manifestou sua surpresa: "Mas como, Paulo, uma Pedagogia da Esperança no bojo de uma tal semvergonhice como a que nos asfixia hoje, no Brasil?" (FREIRE, 1992, p.9).

Paulo Freire, além de esperançoso, foi sempre um encantado com a educação e com a força da mesma como alternativa de libertação das grandes camadas populares brasileiras. E esse encantamento se manifestava mesmo nas horas mais difíceis. Diga-se, que é nessas horas - difíceis 
- em que tudo parece desmoronar, em que as alternativas desapareceram, em que a desesperança toma conta, em que muitos desistem e caem no ceticismo, é que as pessoas raras têm seu papel histórico e político mais importante. Freire foi uma dessas pessoas raras. Freire representou, da melhor maneira possível, a condição de um intelectual na sociedade em que viveu. Intelectual no sentido mais poderoso e generoso dessa expressão: aquele que busca entender o mundo e o tempo em que vive. Fazia isso não por diletantismo, mas, sim, pela vontade de transformá-lo.

Freire não se importava nem mesmo quando uns tantos faziam pouco ou o taxavam de ingênuo ao propor sonhos, ao defender utopias. Talvez, algo que ajudava a deixar seus críticos ainda mais desconcertados era a forma como Freire apresentava suas alternativas. O fazia com muita firmeza, porém, com uma ternura, uma boniteza que desarmava mesmo as mentes mais empedernidas, pelo menos na sua frente. Freire deixou marcas por onde passou. E não foram marcas quaisquer. Foram marcas profundas deixadas com doçura e com mansidão. Ele próprio, mais de uma vez, expressou que se considerava uma pessoa, um sujeito manso.

Freire nos deixou várias construções epistemológicas muito fortes. Uma delas foi a do inédito viável. Em Pedagogia da Esperança (duas décadas após o Pedagogia do Oprimido) Freire evoca a necessidade de retomar-se a ideia. Freire quis mostrar que aquilo que parece ser uma impossibilidade em uma dada situação ou condição, pode ser mudada. Situações que se apresentam como imutáveis nem sempre o são. Afinal, Freire sentencia: a realidade não é assim, está assim! Essa frase é como um chamamento à resistência no momento atual em que vivemos. É como uma convocação à participação, um desafio a continuar esperançando, por mais fortes que sejam os ataques e tentativas de desqualificação que Freire e seu legado estejam sofrendo. Esperança do verbo esperançar, justamente para reafirmar a necessidade do pensar crítico, da ação, da não aceitação das situações, simplesmente, como se apresentam. Para Freire a existência humana se faz e refaz na esperança e no sonho. Ele não se cansava de reafirmar que sua esperança não era suficiente, mas, sim, necessária. Não acreditava que a esperança por si só, fosse capaz de transformar a realidade. Por isso, defendia que se faz necessário partir para a ação, para a busca daquilo que se acredita e que se acha justo. A esperança sozinha não nos faz avançar, contudo, sem ela, nossa vontade de realizar os sonhos corre o sério risco de fraquejar. Nas suas palavras,

Minha esperança é necessária, mas não é suficiente. Ela, só, não ganha a luta, mas sem ela a luta fraqueja e titubeia. Precisamos da esperança crítica, como o peixe precisa da água despoluída... Pensar que a esperança sozinha transforma o mundo e atuar movido por tal ingenuidade é um modo excelente de tombar na desesperança, no pessimismo, no fatalismo... É por isso que não há esperança na pura espera, nem tampouco se alcança o que se espera na espera pura, que vira, assim, espera vã (FREIRE, 1992, p. 11).

O verbo esperançar é a materialização na prática da busca incessante da realização dos sonhos, sem os quais, segundo Freire, não há existência humana. A potência das proposições freireanas e a pertinência da leitura atualizada de Pedagogia do Oprimido se mostra, mais do que nunca, uma necessidade histórica. Até porque, talvez em poucos outros momentos da história de nosso país tenhamos vivido uma época em que a necessidade de transformação, de necessidade de tanta criação e invenção tenha sido tão urgente como nos tempos atuais. Mais uma vez a atualidade de Pedagogia do Oprimido soa como um clamor, quando Freire escreveu: "Só existe saber na invenção, na reinvenção e na busca inquieta, impaciente, permanentemente, que os homens fazem no mundo, com o mundo e com os outros. Busca esperançosa também" (FREIRE, 2016, p. 105). Freire deposita suas esperanças no(a) educando(a) mais que em qualquer outra possibilidade. Esperança nesses educandos e educandas sujeitos de sua história, contudo, isso só acontece quando os(as) educandos(as) se fazem realmente, participantes do processo de aprendizagem "Educando quando e na medida em que conhece, ou vai conhecendo os conteúdos, os objetos cognoscíveis, e não na medida em que o educador vai depositando nele a descrição dos objetos, ou dos conteúdos" (FREIRE, 1992, p. 47).

É com esse modo de abraçar a esperança que Freire não a vê como uma espera van, mas, sim, um compromisso com a história vivida pelas gentes do Brasil. Essa esperança se alicerça, se enraíza na crença freireana de que homens e mulheres são seres "inconclusos" e, como tal, seres em permanente transformação de si e das suas realidades. Em função dessa condição, Freire toma os seres humanos como seres que "estão sendo", seres do inacabamento. Como alerta Freire, a história é uma construção inacabada, e tendo a história como uma construção radicalmente humana, a realidade também é uma construção permanente, portanto, inacabada. Nas palavras de Freire: "[...] Cuando hoy día los "pragmáticos" del neoliberalismo dicen: "Paulo Freire Fue", yo les digo - sin enojo pero con absoluta convicción -: no, Paulo Freire no fue, Paulo Freire sigue siendo" (FREIRE, 2003a, p. 79).

$\mathrm{Na}$ a perspectiva freireana de pensar e fazer a educação ela é algo que está o tempo todo em um processo de construção, está a cada momento se refazendo. Nas palavras de Freire, a educação como "Um quefazer permanente. Permanentemente, na razão da inconclusão dos homens e do devenir da realidade... Dessa maneira a educação se refaz constantemente na práxis. Para ser tem que estar sendo" (FREIRE, 2016, p. 127). 
Aqui se faz materializada uma das diferenças fundamentais entre uma educação "bancária" e uma educação libertadora. Enquanto a primeira se constrói pela acomodação, pela mesmice, pela insistente repetição dos conteúdos, a segunda valoriza o sonho, os desejos, não teme - ao contrário - promove ativamente a reflexão, a ação, a problematização das dificuldades, a rebeldia contra as injustiças, aposta na superação das barreiras interpostas por uma dada realidade. A superação dessas dificuldades e barreiras é o primeiro passo para a ampliação dos limites impostos e para a realização do inédito viável proposto, sabiamente, por Paulo Freire.

Não é raro, ao nos encontrarmos no ambiente de trabalho com colegas professores(as), tanto da educação básica quanto das universidades, percebemos, tristemente, como ainda se fazem presentes escolhas pedagógicas e metodologias onde a opção - às vezes consciente, outras inconscientes - é por práticas educativas de uma educação bancária. Meio século passado da primeira publicação do Pedagogia do Oprimido, pode-se ainda perceber como suas proposições educativas se fazem ausentes em muitas situações reais, de nossas escolas reais, de nossos educandos e educandas reais.

Contudo, o próprio Paulo Freire nos dá sinalizações de caminhos possíveis. Um desses caminhos é o caminho da esperança, do sonho, do acreditar na educação como uma chave que poderá abrir portas para a inclusão, para a cidadania, particularmente para os grandes contingentes de brasileiros e de brasileiras que ainda lhes tem negado o acesso a uma educação que promova a liberdade, a democracia e o respeito aos direitos humanos de todas as pessoas. Como alertava Freire, a educação sozinha não transforma o mundo, o que ela pode é transformar as pessoas. Pessoas, essas, sim, serão capazes de transformar o mundo.

Nos tempos difíceis da conjuntura política brasileira que estamos vivendo, de surgimento de uma onda neoconservadora em todas as dimensões da sociedade, onde uns tantos propõem a expulsão de Freire e de seu legado das escolas e mesmo das universidades, é preciso aprofundarmos e atualizarmos a leitura e a compreensão do legado freireano. Ou seja: aos que propõem "escolas sem partido" e expulsão de Freire 5 , devemos responder com mais Freire e com mais democracia. Se tivéssemos conseguido fazer as proposições freireanas mais presentes, mais encarnadas em nossa educação, certamente alguns ressurgimentos obscurantistas não teriam tanta facilidade de se instalar em nossa sociedade.

\footnotetext{
5 Denominação de um movimento surgido no ano de 2004, por iniciativa do Procurador do Estado de São Paulo Miguel Nagib. O Projeto tinha como intenção combater o que denominava, o então Procurador, de instrumentalização do ensino para fins político ideológicos e partidários. Mais recentemente com a eleição a presidente do Brasil de Jair Messias Bolsonaro (2018), esse movimento retorna no contexto de um discurso que prega a retirada das ideias e proposições freireanas do contexto da educação brasileira.
}

Ao contrário de certos brados obscurantistas vejo uma longa vida para o Pedagogia do Oprimido, entre educadores(as) desse tão maltratado País, onde a "malvadeza" das elites reacionárias - como dizia Freire - insiste em produzir injustiças. Com esse sincero texto, que ora ofereço aos possíveis leitores e leitoras, não quero muito, porém, quero um pouco. Um pouco de diálogo, um pouco menos de intolerância entre homens e mulheres, um pouco de esperança, um pouco de alegria no fazer docente, um pouco mais de generosidade entre as pessoas.

Quero encerrar esse texto com a última frase com a qual Freire finaliza seu Pedagogia do Oprimido, quando ele aposta na "Fé nos homens e na criação de um mundo em que seja menos difícil amar" (FREIRE, 2016, p. 284).

\section{REFERÊNCIAS}

BEISIEGEL, Celso de Rui. Prefácio. In: FREIRE, Paulo. Pedagogia do Oprimido. 60. ed. Rio de Janeiro: Paz e Terra, 2016.

FIORI, E. M. Prefácio. In: FREIRE, Paulo. Pedagogia do Oprimido. 60. ed. Rio de Janeiro: Paz e Terra, 2016.

FREIRE, P. Pedagogia do Oprimido. Rio de Janeiro. Paz e Terra, 2016.

FREIRE, P. Política e Educação. São Paulo: CORTEZ, 2003a.

FREIRE, P. Pedagogia da Autonomia: saberes necessários à pratica docente. Rio de Janeiro: Paz e Terra, 1997. https://doi. org/10.18764/2446-6549.2019.10355

FREIRE, P. Pedagogia da Esperança: um reencontro com a Pedagogia do Oprimido. Rio de Janeiro: Paz e Terra, 1992a. https://doi.org/10.22294/eduper/ppge/ufv.v9i3.1108

FREIRE, P. El grito manso. Buenos Aires: Siglo Veintiuno, $2003 b$.

FREIRE, P. Educação como prática da liberdade. Rio de Janeiro: Paz e Terra, 1992b.

FREIRE, P. La voz del maestro: Acerca de vivir, enseñar y transformar el mundo. Conversaciones con Edson Passetti. Buenos Aires: Siglo Veintiuno, 2018.

Recebido em: 16/3/2019.

Aprovado em: 22/10/2019.

Publicado em: 21/12/2019.

Endereço para correspondência:

Valdo Hermes de Lima Barcelos

Rua Evaristo Tonin, 399 - Itararé

97045-180, Santa Maria RS, Brasil

\section{Autor:}

Valdo Hermes de Lima Barcelos

Pós-Doutorado em Antropofagia Cultural Brasileira. Professor Titular da

Universidade Federal de Santa Maria (UFSM), Departamento de Administração

Escolar. Santa Maria, RS, Brasil.

Orcid: http://orcid.org/0000-0001-7768-1543

E-mail: vbarcelos@terra.com.br 